\title{
Mechanical and Dynamical Properties of High Performance Concrete Using Arecaceae Fiber
}

\author{
R. M. Saravana Kumar, S. Sivaranjani
}

\begin{abstract}
The purpose of this endeavor is to acquire learning for arranging the working with negligible exertion material (arecaceae fiber) using normal fibre.Because trademark fiber can be one possible material which are trashy and locally available.Among all regular fiber coir fiber are picked because of its most important malleability quality. The static direct of arecaceae fiber stronghold concrete essential part is in every practical sense cloud .In this work the effect of fiber content on properties of AFRC is considered. To survey the capability of coif fiber in improving the properties of the strong the first class of plain cement is used as reference. The mechanical properties, for instance, compressive quality, part rigidity, modulus of break and quick chloride entrance test were resolved for all ARFC and Plain Cement models. Likewise the fiber in appropriate sum should be selected.(i.e.,) fiber substance of $2 \%$ and $3 \%$ by weight of bond and having a length of $6.5 \mathrm{~cm}$ are used to design AFRC.
\end{abstract}

Key words : Arecaceae fiber, Coir fiber.

\section{ARECACEAE FIBRE :}

Coconut fiber is isolated from the outer shell of the coconut. Basic Name - Coir

Logical Name - Cocos Nucifera

Plant Name - Arecaceae (Palm)

There are two sorts of coconut fiber dim hued fiber expelled from created coconut and white fiber from energetic coconut.Brown fiber are thick, strong and high bendable quality yet white fiber are smoother and better yet additionally weaker. So in building dark colored fiber are generally utilized.

\section{SCOPE OF THE STUDY}

The key purpose of the endeavor is to upgrade the versatile property of bond by including arecaceae fiber. To convey a viable "Green strong material "using typical fiber (arecacea) will assemble the flexible quality and reduction the existence cost of the structure. This endeavor will make others to extend the energy for look at ordinary fiber and addition the use of ordinarily available materials.

\section{INGREDIENTS USED IN CONCRETE}

Revised Manuscript Received on October 30, 2019

* Correspondence Author

RM..Saravana*, Kumar,Assistant Professor, Department of Civil Engineering, Vel Tech Rangarajan Dr.Saguntala R\&D Institute of Science and Technology Chennai - 600 062, Tamilnadu, India.

S.Sivaranjani,Assistant Professor, Department of Civil Engineering, Vel Tech Rangarajan Dr.Saguntala R\&D Institute of Science and Technology Chennai - 600 062, Tamilnadu, India.

(C) The Authors. Published by Blue Eyes Intelligence Engineering and Sciences Publication (BEIESP). This is an open access article under the CC BY-NC-ND license (http://creativecommons.org/licenses/by-nc-nd/4.0/)

\section{A.CEMENT:}

Bonding is the most fundamental fixing in cement. One of the basic criteria for the decision of bond is its ability to make improved microstructure in cement.

Properties of cement :

Specimen

Normal consistency

Initial setting time

Final setting time

Specific gravity

:OPC 43 GRADE

: $31.7 \%$

: 1 hr 10 min

: 10 hr $38 \mathrm{~min}$

$: 3.09$

\section{B.FINE AGGREGATE:}

The sand got from stream beds is utilized as fine total. The fine total alongside the hydrated concrete glue fill the space between the coarse total. Waterway sand was utilized as the common fine total. Its properties were tried according to May be: 2386.The test aftereffects of sifter investigation is exhibited in beneath tables

Table I Sieve Analysis of fine aggregate

\begin{tabular}{|l|l|l|}
\hline $\begin{array}{l}\text { IS Sieve Size } \\
(\mathrm{mm})\end{array}$ & $\begin{array}{l}\text { Percentage of } \\
\text { Passing }\end{array}$ & $\begin{array}{l}\text { Requirement as } \\
\text { per zone II } \\
\text { (IS 383-1970) }\end{array}$ \\
\hline $10 \mathrm{~mm}$ & 100 & 100 \\
\hline $4.75 \mathrm{~mm}$ & 98 & $90-100$ \\
\hline $2.36 \mathrm{~mm}$ & 83.27 & $75-100$ \\
\hline $1.18 \mathrm{~mm}$ & 67.1 & $55-90$ \\
\hline 600 microns & 39.7 & $35-59$ \\
\hline 300 microns & 15 & $8-30$ \\
\hline 150 microns & 3.4 & $0-10$ \\
\hline 75 microns & 2.10 & \\
\hline
\end{tabular}

Properties of river sand : The physical properties fine aggregate of were done according to IS 2386-1963.
Bulk density
Specific gravity
: $1.760 \mathrm{Kg} / \mathrm{lit}$
: 2.53

\section{COURSE AGGREGATE:}

The Coarse Aggregate of size $60 \%$ of $20 \mathrm{~mm}$ and $40 \%$ of $10 \mathrm{~mm}$ aggregate for the preparation of concrete.

Properties of coarse aggregate: For $20 \mathrm{~mm}$

Bulk density $\quad: 1.7 \mathrm{~kg} / \mathrm{lit}$

Specific gravity : 2.89 (Surface Saturated Dry Condition Method)




Specific gravity : 2.64 (Pycnometer method)

By using Sieve Analysis we confirm the $20 \mathrm{~mm}$ aggregate as per code IS 383-1970

\section{D.WATER}

Water conforming to the requirements is found to be suitable for making concrete.

\section{Water Absorption Results:}

For fine aggregate $-2.420 \%$

For $20 \mathrm{~mm}$ coarse aggregate- $1.240 \%$

For $10 \mathrm{~mm}$ coarse aggregate- $1.586 \%$

\section{E. ADMIXTURE}

Table II Properties of Admixture

\begin{tabular}{|l|l|}
\hline Name & CONPLAST 230 \\
\hline Type & Water reducing agent \\
\hline Base & Napthalene \\
\hline Workability & $\begin{array}{l}\text { Produce high workable flowing } \\
\text { concrete mix }\end{array}$ \\
\hline
\end{tabular}

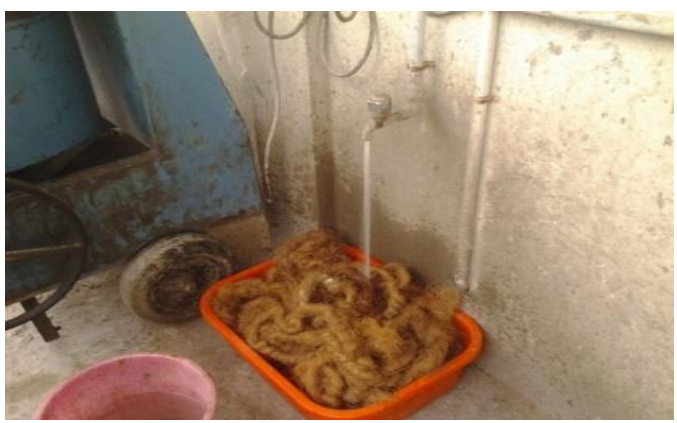

Fig (A) Arecaceae Fiber

IV.TEST DONE FOR THE SPECIMENS

- Compression test

- Flexural strength or modulus of rupture

- Split tensile test

- $\quad$ Rapid chloride penetration test (RCPT)

Table III Specimen Details

\begin{tabular}{|l|l|l|l|l|l|l|}
\hline Sp's & \multicolumn{3}{|c|}{ 7days } & \multicolumn{3}{c|}{28 days } \\
\hline & $\begin{array}{l}\text { C. } \\
\text { S }\end{array}$ & $\begin{array}{l}2 \% \\
\text { CFRC }\end{array}$ & $\begin{array}{l}3 \% \\
\text { CFR } \\
\text { C }\end{array}$ & C.S & $\begin{array}{l}2 \% \\
\text { CF } \\
\text { RC }\end{array}$ & $\begin{array}{l}3 \% \\
\text { CFR } \\
\text { C }\end{array}$ \\
\hline Cube & 3 & 3 & 3 & 3 & 3 & 3 \\
\hline Cylinder & 3 & 3 & 3 & 3 & 3 & 3 \\
\hline Beam & 3 & 3 & 3 & 3 & 3 & 3 \\
\hline $\begin{array}{l}\text { Cylinder } \\
\text { for RCPT }\end{array}$ & 1 & 1 & 1 & 1 & 1 & 1 \\
\hline
\end{tabular}

A.REQUIREMENT FOR $1 \mathrm{~m}^{3}$ OF CONCRETE

Retrieval Number F7986088619/2019@BEIESP

DOI: 10.35940/ijeat.F7986.088619

Journal Website: www.ijeat.org

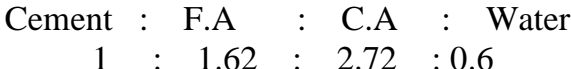
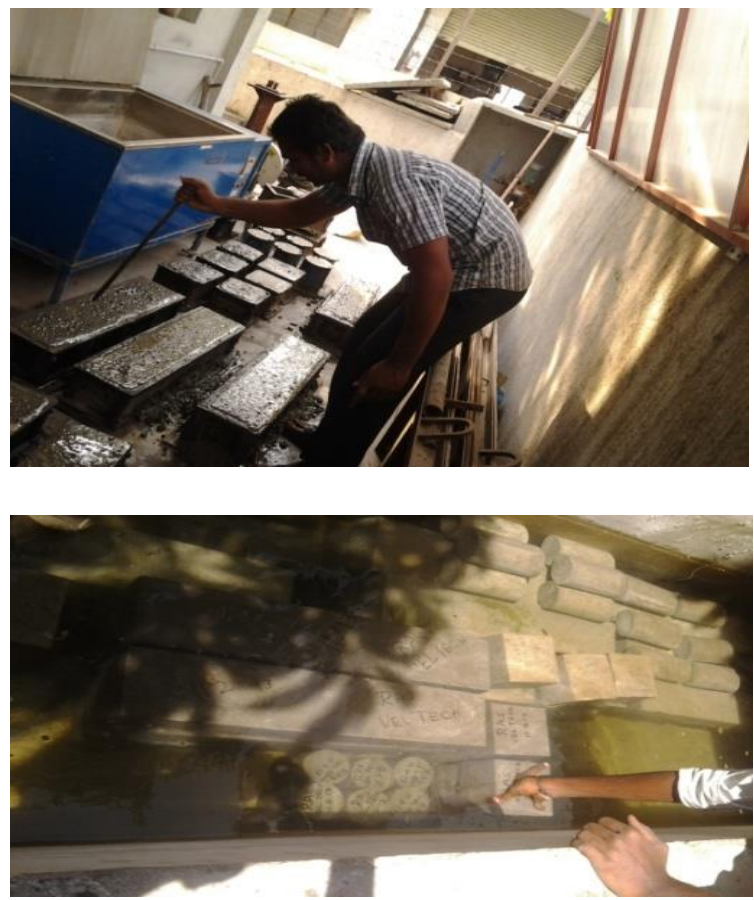

Fig(B) Curing Of Specimens

\section{RESULT AND DISCUSSIONS}

\section{A. COMPRESSIVE STRENGTH}

Solid shape of size $150 \mathrm{~mm} \times 150 \mathrm{~mm} \times 150 \mathrm{~mm}$ were thrown for M40 review of cement. The plain concrete, $2 \%$ of CFRC and $3 \%$ of CFRC were tried for 7days and 28th days compressive strength.The7 days and 28 days comes about were looked at in beneath graphs

Table IV Compressive Strength Results

\begin{tabular}{|l|l|l|l|l|}
\hline \multirow{2}{*}{ SPECIMEN } & \multicolumn{2}{|l|}{7 DAYS } & \multicolumn{2}{l|}{ 28 DAYS } \\
\cline { 2 - 5 } & $\begin{array}{l}\text { FAILUR } \\
\text { E LOAD } \\
(\mathrm{KN})\end{array}$ & $\begin{array}{l}\text { STRESS } \\
\left(\mathrm{N} / \mathrm{mm}^{2}\right. \\
)\end{array}$ & $\begin{array}{l}\text { FAILUR } \\
\text { E } \\
\text { LOAD } \\
(\mathrm{KN})\end{array}$ & $\begin{array}{l}\text { STRESS } \\
\left(\mathrm{N} / \mathrm{mm}^{2}\right. \\
)\end{array}$ \\
\hline CONTROL & 1044 & 46.4 & 1192.27 & 52.99 \\
\hline 2\% CFRC & 963.9 & 42.84 & 1071.45 & 47.62 \\
\hline 3\% CFRC & 1065.37 & 47.35 & 1234.35 & 54.86 \\
\hline
\end{tabular}

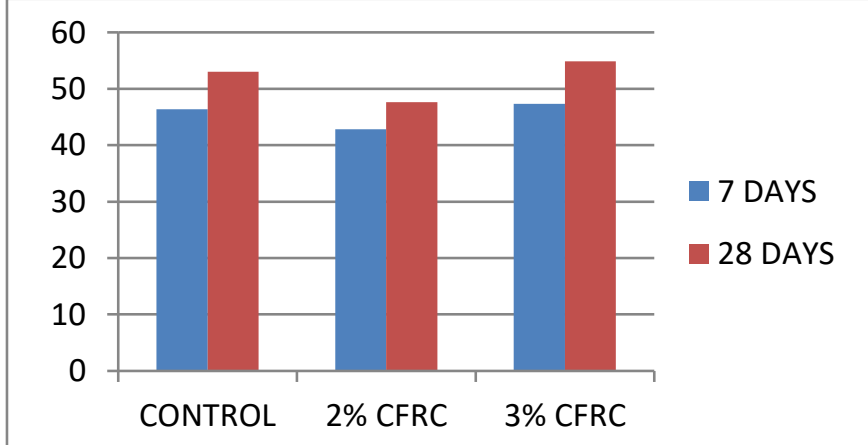

Fig (C) Comparison Of Results




The above diagrams demonstrates the consequences of compressive quality for the examples on both 7 days and 28 days. From the outcome the 3\%CFRC achieve more compressive quality when contrasted with control and $2 \%$ CFRC.



Fig(D) Failure of control specimen having stress of $\mathbf{4 6 . 4 0}$ $\left(\mathrm{N} / \mathbf{m m}^{2}\right)$

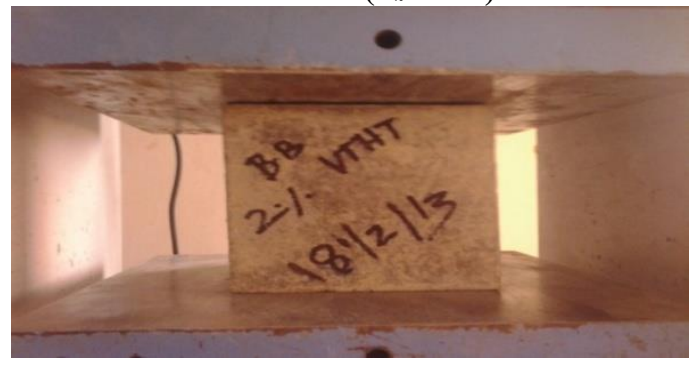

Fig (E) Failure of $2 \%$ CFRC specimen having stress of $42.84\left(\mathrm{~N} / \mathrm{mm}^{2}\right)$

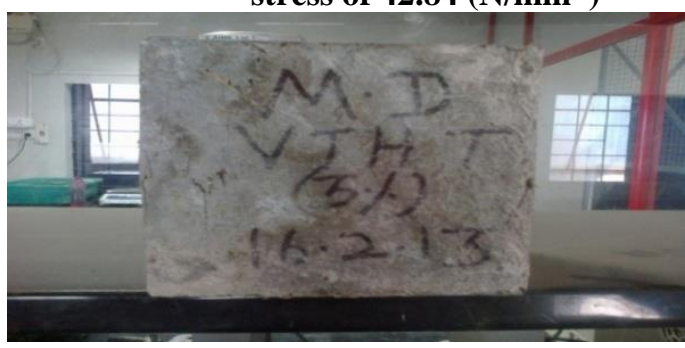

Fig (F) Failure of $3 \%$ CFRC specimen having stress of $47.37\left(\mathrm{~N} / \mathrm{mm}^{2}\right)$

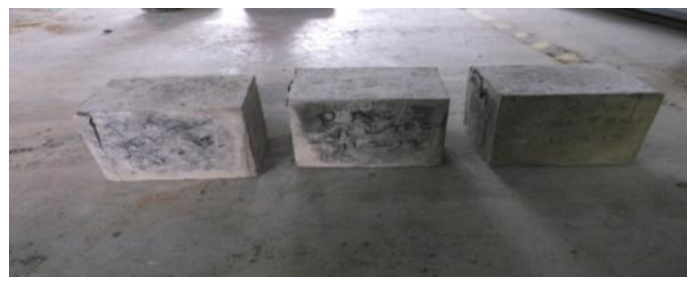

Fig 7(G) Failure of control specimen having stress of $52.99\left(\mathrm{~N} / \mathrm{mm}^{2}\right)$

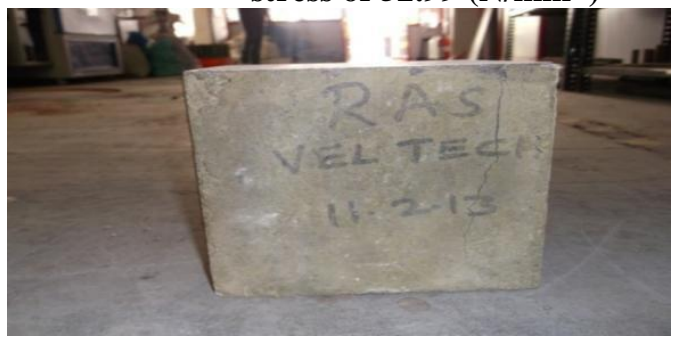

Fig 8(H) Failure of $2 \%$ CFRC specimen having stress of $47.62\left(\mathrm{~N} / \mathrm{mm}^{2}\right)$

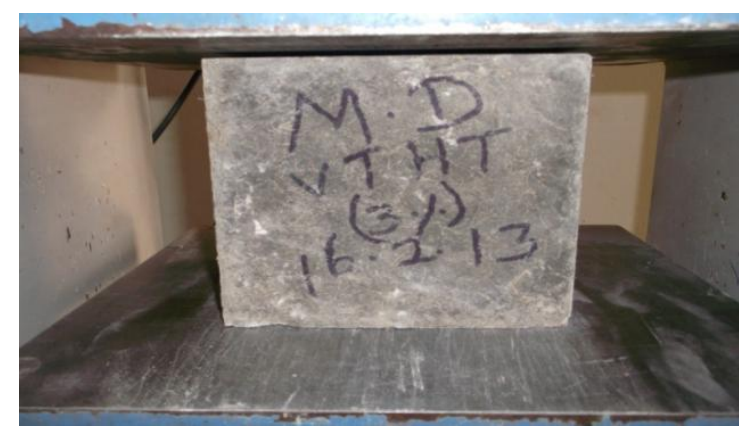

Fig (I) Failure of $3 \%$ CFRC specimen having stress of $54.86\left(\mathrm{~N} / \mathrm{mm}^{2}\right)$

\section{B.FLEXURAL STRENGTH}

Solid light emissions $150 \mathrm{~mm}$ x 150mm x 700mm were thrown for M40 review of cement. The plain concrete, $2 \%$ of CFRC and 3\% of CFRC were tried for 7days and 28th days flexural quality. The7 days and 28 days comes about were looked at in beneath outlines

Table V Flexural Strength Result

\begin{tabular}{|l|l|l|l|l|}
\hline \multirow{2}{*}{$\begin{array}{l}\text { SPECIME } \\
\text { S }\end{array}$} & \multicolumn{2}{|l|}{7 DAYS } & \multicolumn{2}{l|}{28 DAYS } \\
\cline { 2 - 5 } & $\begin{array}{l}\text { FAILU } \\
\text { RE } \\
\text { LOAD } \\
(\mathrm{KN})\end{array}$ & $\begin{array}{l}\text { STRESS } \\
\left(\mathrm{N} / \mathrm{mm}^{2}\right. \\
)\end{array}$ & $\begin{array}{l}\text { FAILU } \\
\text { RE } \\
\text { LOAD } \\
(\mathrm{KN})\end{array}$ & $\begin{array}{l}\text { STRES } \\
\text { S } \\
(\mathrm{N} / \mathrm{mm} \\
2\end{array}$ \\
\hline C.S & 25.25 & 4.49 & 30.99 & 5.51 \\
\hline 2\% CFRC & 24.07 & 4.28 & 27.73 & 4.93 \\
\hline 3\% CFRC & 29.75 & 5.29 & 36.84 & 6.55 \\
\hline
\end{tabular}



Fig (J) Comparison Of Results

The above outlines demonstrates the consequences of flexural quality for the examples on both 7 days and 28 days. From the outcome the 3\%CFRC achieve more flexural quality when contrasted with control and 2\% CFRC Flexural Strength For Control Specimen The Failure Load Is 27.55 Kn In 7 Days

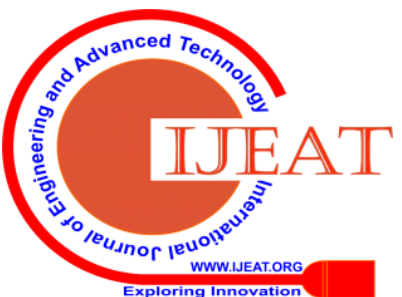


Mechanical and Dynamical Properties of High Performance Concrete Using Arecaceae Fiber

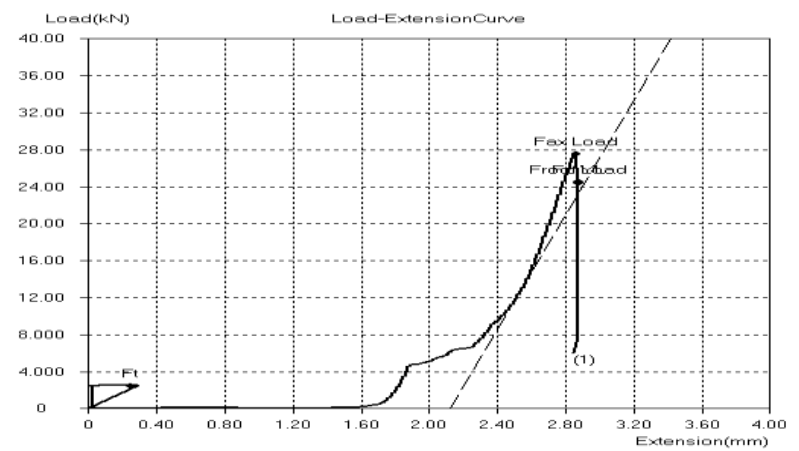

Fig (K) Flexural Strength For Control Specimen The Failure Load Is $29.5 \mathrm{Kn}$ In 28 Days

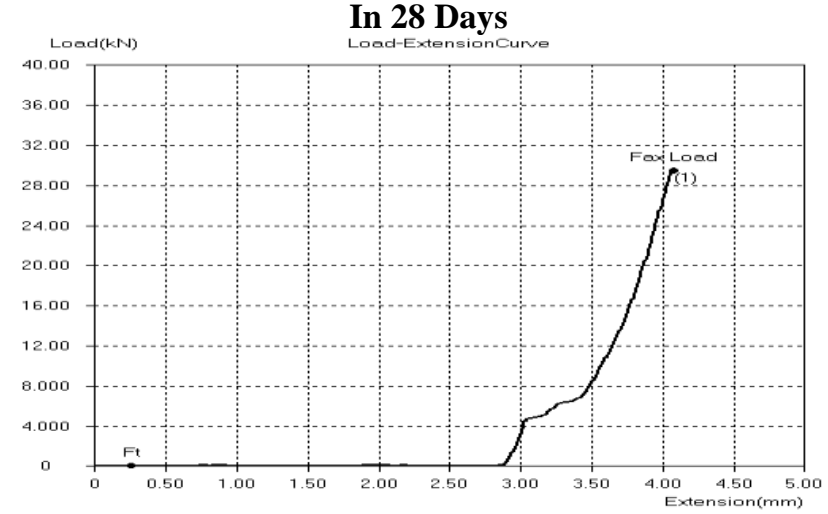

Fig (L) Flexural Strength For 2\%Cfrc Specimen The Failure Load Is $23.75 \mathrm{Kn}$ In 7 Days

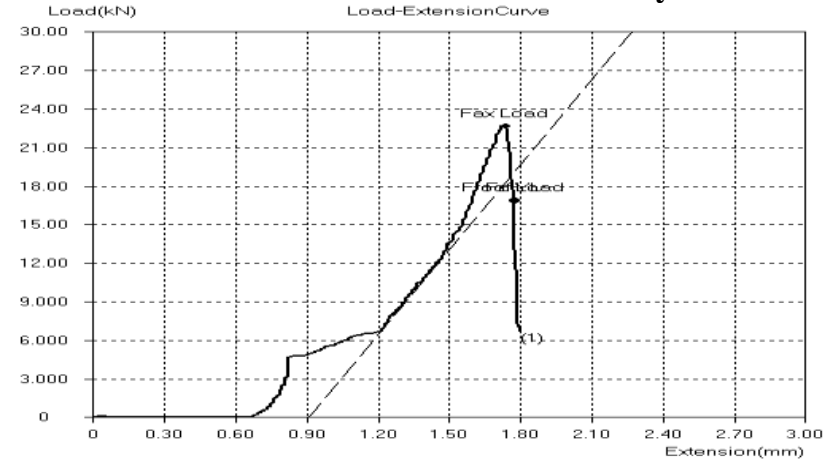

Fig (M) Flexural Strength For 2\%Cfrc Specimen The Failure Load Is 27.5 Kn In 28 Days

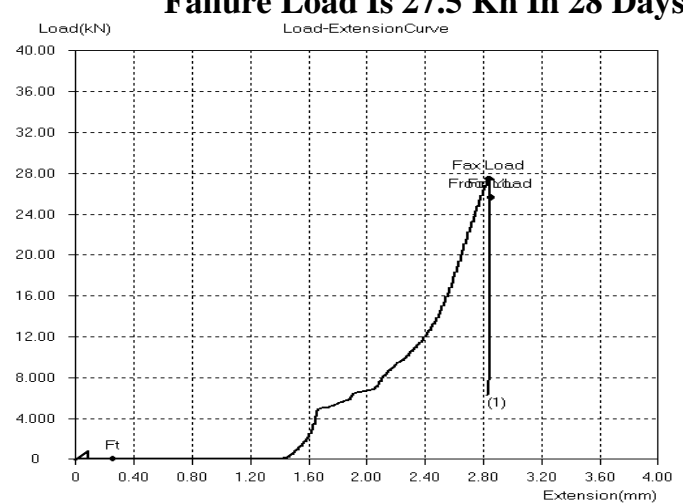

Fig (N) Flexural Strength For 3\%Cfrc Specimen The Failure Load Is 30.50 Kn In 7 Days



Fig (O) Flexural Strength For 3\%Cfrc Specimen The Failure Load Is 33 Kn In 28 Days
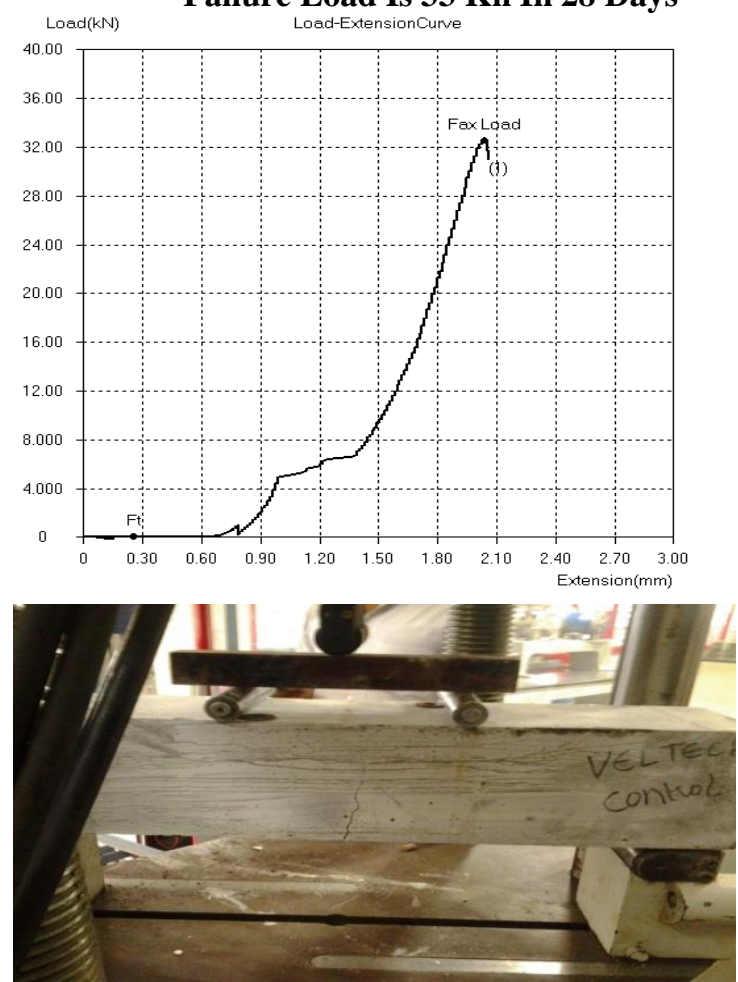

Fig (P) Failure of control specimen having stress of $4.49\left(\mathrm{~N} / \mathrm{mm}^{2}\right)$

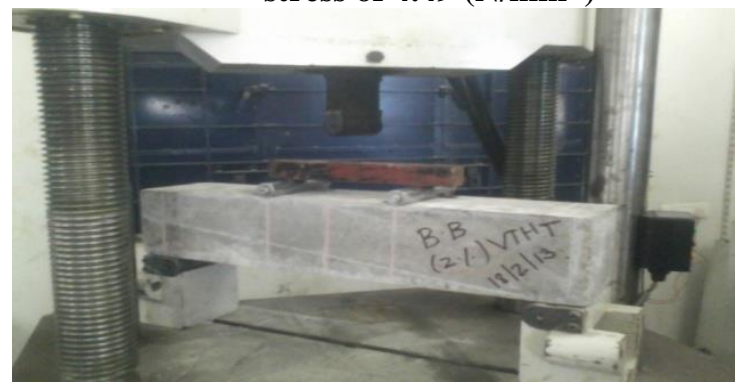

Fig (Q) Failure of $2 \%$ CFRC specimen having stress of $4.28\left(\mathrm{~N} / \mathrm{mm}^{2}\right)$

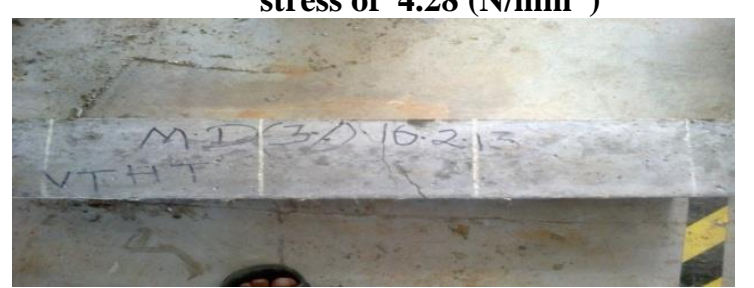

Fig (R) Failure of 3\% CFRC specimen having stress of $5.29\left(\mathrm{~N} / \mathrm{mm}^{2}\right)$

Published By:

DOI: 10.35940/ijeat.F7986.088619

Journal Website: www.ijeat.org






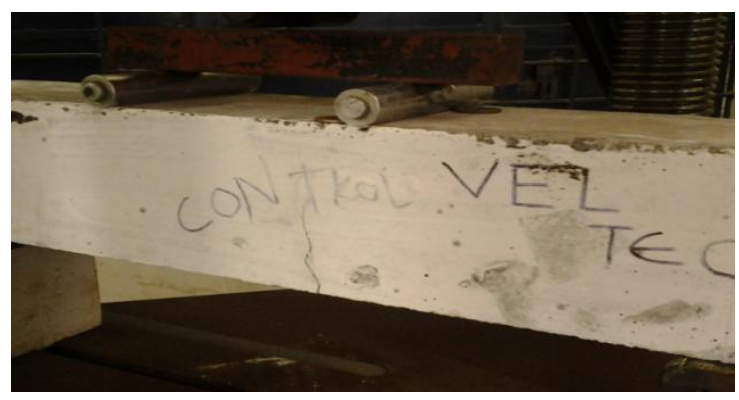

Fig (S) Failure of control specimen having

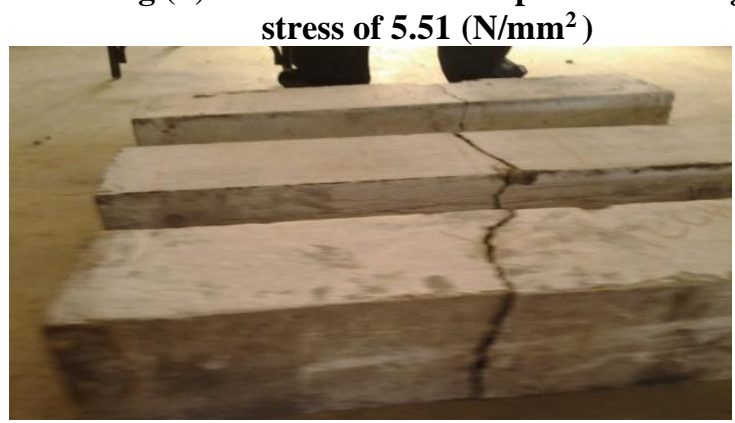

Fig (T) Failure of 2\% CFRC specimen having stress of $4.93\left(\mathrm{~N} / \mathrm{mm}^{2}\right)$



Fig (U) Failure of $3 \%$ CFRC specimen having stress of $6.55\left(\mathrm{~N} / \mathrm{mm}^{2}\right)$

\section{C.SPLIT TENSILE STRENGTH}

Solid barrels of distance across 100mm Dia x 200mm stature were thrown M40 review of cement .The plain concrete, $2 \%$ of CFRC and 3\% of CFRC were tried for 7days and 28th days split elasticity. The7 days and 28 days comes about were analyzed in underneath graphs.

\section{Table 6 Results}

\begin{tabular}{|l|l|l|l|l|}
\hline \multirow{2}{*}{ SPECIME } & \multicolumn{3}{|l|}{ 7 DAYS } & \multicolumn{2}{l|}{ 28 DAYS } \\
\cline { 2 - 5 } & $\begin{array}{l}\text { FAILUR } \\
\text { E LOAD } \\
(\mathrm{KN})\end{array}$ & $\begin{array}{l}\text { STRES } \\
\text { S } \\
\left(\mathrm{N} / \mathrm{mm}^{2}\right. \\
)\end{array}$ & $\begin{array}{l}\text { FAILUR } \\
\text { E } \\
\text { LOAD } \\
(\mathrm{KN})\end{array}$ & $\begin{array}{l}\text { STRES } \\
\text { S } \\
\left(\mathrm{N} / \mathrm{mm}^{2}\right. \\
)\end{array}$ \\
\hline $\begin{array}{l}\text { CONTRO } \\
\text { L }\end{array}$ & 120 & 3.82 & 130.69 & 4.16 \\
\hline 2\% CFRC & 116.86 & 3.72 & 128.89 & 4.103 \\
\hline 3\% CFRC & 127.86 & 4.07 & 184.41 & 5.87 \\
\hline
\end{tabular}

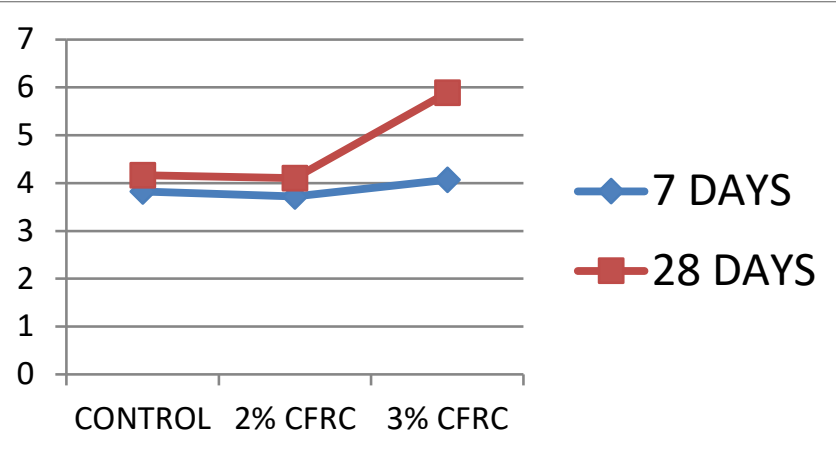

Fig (V) Comparison Of Results

The above outlines demonstrate the aftereffects of split rigidity for the examples on both 7 days and 28 days. From the outcome the 3\%CFRC achieve more Split rigidity when contrasted with control and 2\% CFRC .



Fig 2(W) Failure of control specimen having stress of $3.82\left(\mathrm{~N} / \mathrm{mm}^{2}\right)$

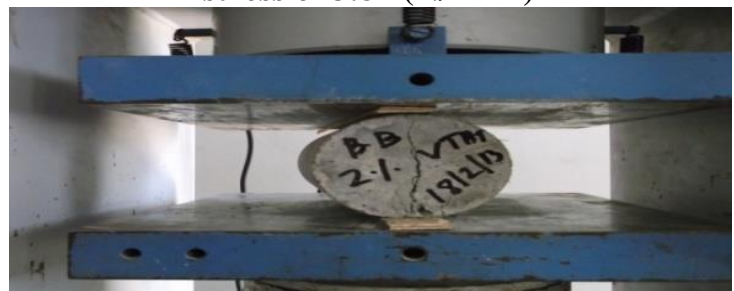

Fig (X) Failure of $2 \%$ CFRC specimen having stress of $3.72\left(\mathrm{~N} / \mathrm{mm}^{2}\right)$

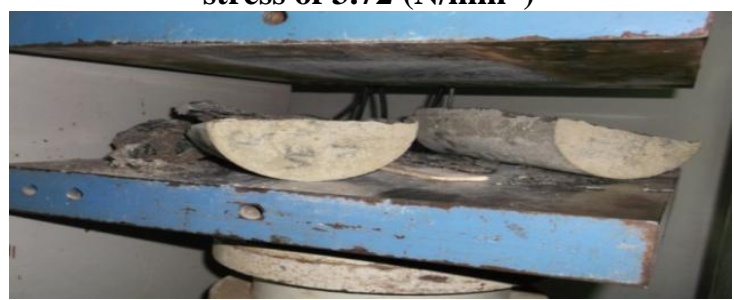

Fig (Y) Failure of control specimen having stress of $4.16\left(\mathrm{~N} / \mathrm{mm}^{2}\right)$

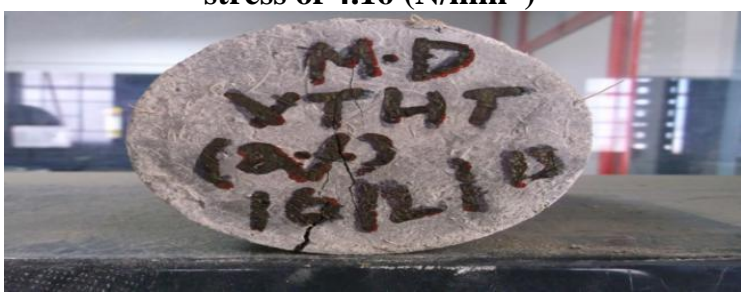

Failure of $2 \%$ CFRC specimen having stress of $4.103\left(\mathrm{~N} / \mathrm{mm}^{2}\right)$

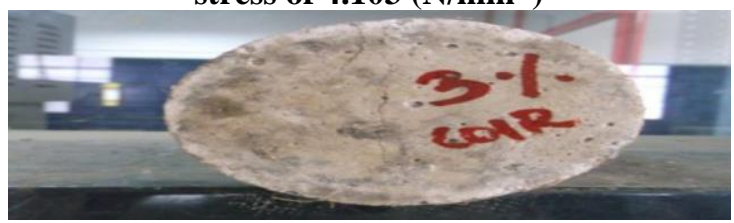

Failure of 3\% CFRC specimen having stress of $5.89\left(\mathrm{~N} / \mathrm{mm}^{2}\right)$




D. RCPT - RAPID CHLORIDE PENETRATION TEST:

- It is one of the strength tests directed in our solid - This test technique covers the assurance of the electrical conductance of cement to give a quick sign of its protection from the entrance of chloride particles.

Table VII CHLORIDE ION PENETRABILITY BASED ON CHARGE PASSED

\begin{tabular}{|c|c|}
\hline $\begin{array}{c}\text { CHARGE } \\
\text { PASSED } \\
\text { (COULOMBS) }\end{array}$ & $\begin{array}{c}\text { CHLORIDE ION } \\
\text { PENETRABILITY }\end{array}$ \\
\hline$>4000$ & HIGH \\
\hline $2000-4000$ & MODERATE \\
\hline $1000-2000$ & LOW \\
\hline $100-1000$ & VERY LOW \\
\hline$<100$ & NEGLIGIBLE \\
\hline
\end{tabular}

From the above table the outcome demonstrates that the control example , 2\% CFRC and 3\% CFRC accomplish low chloride particle entrance. So the solidness of the coir fiber fortification cement (CFRC) is great in light of consequence of chloride assault in the solid
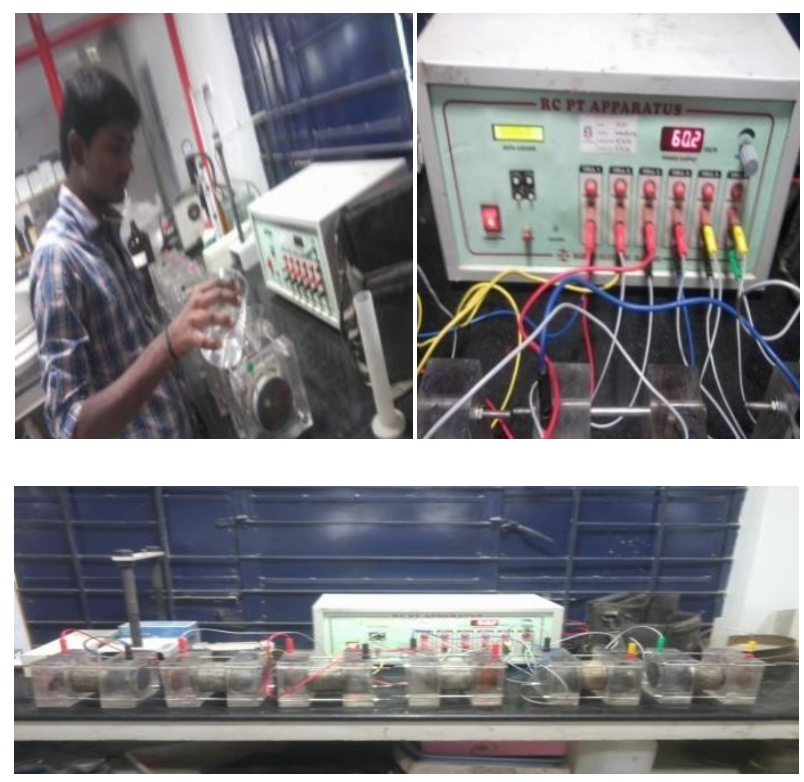

Fig (Z) Exerimental Set Up Of Rcpt

\section{CONCLUSION}

$\square$ The restoring time of 7 days and 28 days comes about exhibits that the $3 \%$ CFRC are higher in quality (compressive ,split malleable and flexural) when appeared differently in relation to $2 \%$ CFRC and the plain concrete.

The connection exhibited that the volume of $3 \%$ coir fiber invigorated concrete had the perfect plan of mechanical properties

Coconut fiber fortified bond has exhibited less number of part progressions . Thusly, it very well may be a conventional choice being a developed area.

$\square$ The snappy chloride passage test comes about that the quality property for the plain concrete and coir fiber bolster cement were less vulnerable against chloride ambush .

Based on the examination of weight it is assumed that coconut fiber can internal curing and infilled walls.



Mrs.s.Sivaranjani, Completed M.E in structural Engineering field having 8 publications in scopus indexed journals and two publications in non scopus indexed journals. Membership recieved from ISTE,IAHS,IAENG,IRED. The research area includes

$\square$ possibly be used as a piece of the age of helper lightweight Table VIII RESULTS OF RCPT

\begin{tabular}{|l|l|l|}
\hline SPECIMENS & $\begin{array}{l}\text { RCPT } \\
\text { RESULTS }\end{array}$ & $\begin{array}{l}\text { CHLORIDE } \\
\text { ION } \\
\text { PANETRATION } \\
\text { ACCORDING } \\
\text { (COULOM } \\
\text { BS) } \\
\text { ASTM C1202-10 } \\
\text { (COULOMBS) }\end{array}$ \\
\hline CONTROL & 1758.60 & LOW \\
\hline $\mathbf{2 \% ~ C F R C ~}$ & 1862.55 & LOW \\
\hline $\mathbf{3 \% ~ C F R C ~}$ & 1884.15 & LOW \\
\hline
\end{tabular}

\section{REFERENCES}

Satyanarayana, K. G., Sukumaran, K., Mukherjee, P. S., Pavithran, Cement And Concretecomposites

Dynamic Properties Of Coir Fibre Reinforced Concrete Beams"

5. Is 2386: Part 1 Method Of Test For Aggregate For Concrete

6. Is 4031:Part 4-1988 Method Of Physical Test For Hydraulic Cement

7. Is 10262:2009 Concrete Mix Proportioning Guidelines

\section{AUTHORS PROFILE}

Mr.R.M.Saravana Kumar , Completed M.E in structural Engineering field having 4 publications in scopus indexed journals and one publications in non scopus indexed journals. Membership recieved from IAHS,IAENG,IRED. The research area includes shear walls and earthquake resistant structures. 